\title{
In situ formation of reduced graphene oxide structures in ceria by combined sol-gel and solvothermal processing
} Jingxia Yang ${ }^{1,2}$, Johannes Ofner ${ }^{3}$, Bernhard Lendl ${ }^{3}$ and Ulrich Schubert ${ }^{* 1}$

\author{
Full Research Paper \\ Address: \\ ${ }^{1}$ Institute of Materials Chemistry, Vienna University of Technology, \\ Getreidemarkt 9, 1060 Wien, Austria, ${ }^{2}$ permanent address: College of \\ Chemistry and Chemical Engineering, Shanghai University of \\ Engineering Science, LongTeng Road 333, 201620 Shanghai, P. R. \\ China and ${ }^{3}$ Institute of Chemical Technologies and Analytics, Vienna \\ University of Technology, Getreidemarkt 9, 1060 Wien, Austria \\ Email: \\ Ulrich Schubert ${ }^{*}$ - Ulrich.Schubert@tuwien.ac.at \\ * Corresponding author \\ Keywords: \\ ceria; CO oxidation; graphene oxide; sol-gel processing
}

Beilstein J. Nanotechnol. 2016, 7, 1815-1821.

doi:10.3762/bjnano.7.174

Received: 23 August 2016

Accepted: 10 November 2016

Published: 23 November 2016

This article is part of the Thematic Series "Hybrid nanomaterials: from the laboratory to the market".

Guest Editor: A. Taubert

(C) 2016 Yang et al.; licensee Beilstein-Institut.

License and terms: see end of document.

\begin{abstract}
Raman and IR investigations indicated the presence of reduced graphene oxide (rGO)-like residues on ceria nanoparticles after solvothermal treatment in ethanol. The appearance of such structures is closely related to cerium tert-butoxide as precursor and ethanol as solvothermal solvent. The rGO-like residues improve the catalytic CO oxidation activity. This was also confirmed by introduction of "external" graphene oxide during sol-gel processing, by which the rGO structures and the catalytic activity were enhanced.
\end{abstract}

\section{Introduction}

Ceria $\left(\mathrm{CeO}_{2}\right)$ has been widely studied as catalyst or catalyst support for redox reactions owing to its high oxygen storage and release capacity. It is mostly used together with other components, such as noble metals or transition metal oxides, such as $\mathrm{NiO}$ or $\mathrm{Co}_{3} \mathrm{O}_{4}$, because synergistic effects improve the catalytic properties. Graphene-modified $\mathrm{CeO}_{2}$ greatly enhances the performance in electrochemical devices (supercapacitors, fuel cells or batteries) [1-7] or (photo-)catalysts [8-16]. The property enhancements are mainly due to the charge transfer between graphene and $\mathrm{CeO}_{2}$. For the preparation of graphene- $\mathrm{CeO}_{2}$ composites external graphene oxide $(\mathrm{GO})$ is usually added to the ceria precursor or pre-synthesized ceria particles followed by reduction to reduced graphene oxide (rGO) [1-16].

In a previous study, we have synthesized $\mathrm{CeO}_{2}$ [17] from cerium tert-butoxide by combined sol-gel and solvothermal processing. The kind of post-synthesis treatment of the gels proved to be crucial for the specific surface area, the $\mathrm{Ce}^{3+}$ proportion and, as a consequence, the $\mathrm{CO}$ oxidation activity of the obtained materials, which were composed of 3.5-5.5 nm ceria nanoparticles. $\mathrm{CeO}_{2}$ solvothermally treated with $\mathrm{EtOH}$ had 
the highest surface area and showed better $\mathrm{CO}$ oxidation activity than the hydrothermally treated samples. A weight loss of ca. $12 \%$ was observed in TGA after solvothermal treatment of the gels with ethanol. This was not the case after hydrothermal treatment (only ca. $4 \%$ ). We interpreted the high weight loss in the former samples to the presence of residual organic groups partly originating from EtOH and possibly associated with the high $\mathrm{Ce}^{3+}$ proportion $(12 \%)$. We now show that the organic residues contain graphene-like structures. Furthermore, external graphene oxide was introduced into the system, to investigate how the graphene-like structures influence the properties and structure of the ceria-graphene composites.

Ceria or its composites are often prepared by solvothermal synthesis using various alcohols. In some reports organic residues on the surface of the ceria particles were noticed, even if ceria was prepared from $\left(\mathrm{NH}_{4}\right)_{2}\left[\mathrm{Ce}\left(\mathrm{NO}_{3}\right)_{6}\right]$, and alkoxide or carboxylate groups were identified [18]. Graphene-like structures, however, were never mentioned.

\section{Experimental Synthesis of rGO-modified $\mathrm{CeO}_{2}$}

The procedure for the preparation of the ceria-rGO composites was the same as previously reported for that of pure ceria [17] (or $\mathrm{Co}_{3} \mathrm{O}_{4}$-modified $\mathrm{CeO}_{2}$ [19]) with the difference that varying proportions of GO were added to the precursor mixture. Graphene oxide (GO) was synthesized by the modified Hummer method [20,21]. All steps involving $\mathrm{Ce}(\mathrm{O} t-\mathrm{Bu})_{4}$ were carried out under moisture-free argon using standard Schlenk or glove box techniques.

$\mathrm{Ce}(\mathrm{O} t-\mathrm{Bu})_{4}(5 \mathrm{mmol})$ was dissolved in 1,2-dimethoxyethane $(10 \mathrm{~mL})$, followed by the addition of acetaldoxime $(10 \mathrm{mmol})$ and stirring for $30 \mathrm{~min}$, addition of the surfactant F127 $(0.025 \mathrm{mmol})$ and additionally stirring for $1 \mathrm{~h}$. No water was added during this stage. Different proportions of GO (0-0.2 g) were then added. The mixture was stirred for $30 \mathrm{~min}$, ultrasonically treated for at least $2 \mathrm{~h}$ and then deposited onto glass sheets $\left(20 \times 30 \mathrm{~cm}^{2}\right)$, which had been cleaned with $10 \% \mathrm{KOH}$, isopropanol and acetone and dried at $100{ }^{\circ} \mathrm{C}$. The deposited films were exposed to ambient humidity at room temperature for $24 \mathrm{~h}$ (for hydrolysis and condensation along with solvent evaporation). The solid films were then scraped off with a razor blade to get a gel powder. The gel from $5 \mathrm{mmol} \mathrm{Ce}(\mathrm{O} t-\mathrm{Bu})_{4}$ was transferred into a $60 \mathrm{~mL}$ autoclave with $30 \mathrm{~mL} \mathrm{EtOH}$, which was sealed, heated to $200{ }^{\circ} \mathrm{C}$ for $6 \mathrm{~h}$ and then cooled to room temperature by means of cold water. The solid was separated by centrifugation, washed at least three times with $\mathrm{EtOH}$ and $\mathrm{H}_{2} \mathrm{O}$ and then dried at $105{ }^{\circ} \mathrm{C}$ overnight. The samples were named $\mathrm{rGO}(x)-\mathrm{CeO}_{2}$ (rGO was used to indicate $\mathrm{GO}$ after solvothermal treatment), where $x$ is the mass of added GO in grams. For the sake of consistency, the sample with organic residues, but without externally added rGO is thus labelled $\mathrm{rGO}(0)-\mathrm{CeO}_{2}$.

\section{Characterization}

Raman spectra and maps were collected on a Horiba Jobin Yvon Micro-Raman spectrometer (LabRam $800 \mathrm{HR}$ ) equipped with an integral Olympus BX 41 microscope $(20 \times$ objective) and a Peltier-cooled CCD detector, using the $632 \mathrm{~nm}$ line of a HeNe laser $(1.5 \mathrm{~mW})$ for excitation. A 600 line grating was used for obtaining the Raman spectra. The Raman-Stokes spectra were recorded in the range of $2500-300 \mathrm{~cm}^{-1}$ at $1.3 \mathrm{~cm}^{-1}$ spectral resolution. The spectrograph was calibrated using the $520 \mathrm{~cm}^{-1}$ Raman band of a Si wafer. Raman mapping was performed using a $10 \times$ magnification objective and a 300 line grating; a $532 \mathrm{~nm}$ (frequency doubled Nd:YAG) DPSS laser was used. An area of $500 \times 500 \mu \mathrm{m}^{2}$ with a lateral resolution of $5 \mu \mathrm{m}$ was mapped by scanning each pixel three times for $1 \mathrm{~s}$.

X-ray powder diffraction (XRD) measurements were performed on a Philips X'Pert diffractometer using $\mathrm{Cu} \mathrm{K \alpha}$ radiation $(\lambda=1.5406 \AA)$. High-resolution transmission electron micrographs (HRTEM) were recorded on a TECNAI F20 operated at $200 \mathrm{kV}$. Before the measurements, the samples were ultrasonically dispersed in $\mathrm{EtOH}$ for $30 \mathrm{~min}$, and then deposited on copper grids covered with carbon films. FTIR spectra with $4 \mathrm{~cm}^{-1}$ resolution were recorded on a Bruker Tensor 27 equipped with an ATR Micro Focusing MVP-QL with a ZnSe crystal, using OPUS 4.0 software for analysis.

Thermogravimetric analysis (TGA) was performed on a Netzsch Iris TG $209 \mathrm{C}$ in a platinum crucible in synthetic air with a heating rate of $10{ }^{\circ} \mathrm{C} / \mathrm{min}$. Nitrogen sorption measurements were performed on an ASAP 2020 (Micromeritics). The samples were degassed in vacuum at room temperature for at least $5 \mathrm{~h}$ prior to measurement. The total surface area was calculated according to Brunauer, Emmett and Teller (BET), and the pore size distribution (from the desorption branch) according to Barrett, Joyner and Halenda (BJH).

$\mathrm{CO}$ oxidation was performed in a continuous-flow fixed-bed quartz reactor under atmospheric pressure. A sample amount of $20 \mathrm{mg}$ was loaded into the reactor and pretreated with synthetic air $\left(30 \mathrm{~mL} / \mathrm{min}\right.$ ) at $200{ }^{\circ} \mathrm{C}$ for $40 \mathrm{~min}$ (heating rate $10{ }^{\circ} \mathrm{C} / \mathrm{min}$ ). Then the sample was cooled to $30{ }^{\circ} \mathrm{C}$ in flowing synthetic air, and a mixture of 5 vol \% CO, 10 vol $\% \mathrm{O}_{2}$ and 85 vol $\% \mathrm{He}$ (total flow $50 \mathrm{~mL} / \mathrm{min}$ ) was introduced. The system was then heated to $650{ }^{\circ} \mathrm{C}$ with a ramping rate of $5{ }^{\circ} \mathrm{C} / \mathrm{min}$. The concentrations of $\mathrm{CO}$ and $\mathrm{CO}_{2}$ in the outlet streams were monitored by gas chromatography with a HP-PLOT Q column and a flame ionization detector. For temperature-programmed reduction of 
CO (CO-TPR) the samples were exposed, after cooling, to a mixture of $5 \mathrm{vol} \% \mathrm{CO}$ and $95 \mathrm{vol} \% \mathrm{He}$ (total flow $50 \mathrm{~mL} / \mathrm{min}$ ) at room temperature. Then the system was ramped up to $900{ }^{\circ} \mathrm{C}$ at a heating rate of $10^{\circ} \mathrm{C} / \mathrm{min}$. The gas stream was analyzed by an online quadrupole mass spectrometer (QMS) (Prisma Plus QMG 220, Pfeiffer Vacuum) equipped with a Faraday detector.

\section{Results and Discussion}

In order to shed light on the nature of the organic residues formed when the ceria gels were supercritically treated with ethanol [17], we performed extensive Raman studies. The sample (named $\mathrm{rGO}(0)-\mathrm{CeO}_{2}$ according to the labelling scheme used in this article) surprisingly showed Raman bands that are attributed to the D- $\left(1388 \mathrm{~cm}^{-1}\right)$ and the G- $\left(1577 \mathrm{~cm}^{-1}\right)$ band of graphene (Figure 1f). As amorphous carbon shows no D-band [22,23], the organic residues have a graphene-like structure, indicating graphene-like structures in the organic residue. Furthermore, the $\mathrm{F}_{2} \mathrm{~g}$ band of $\mathrm{CeO}_{2}$ was also observed at $461 \mathrm{~cm}^{-1}$.

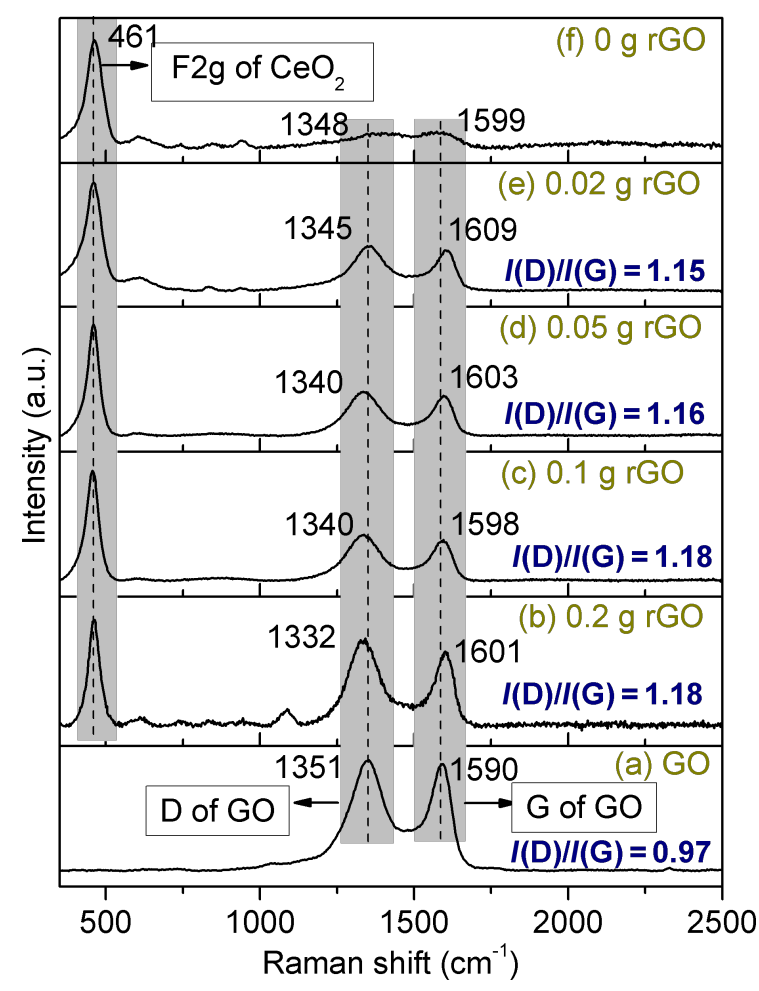

Figure 1: Raman spectra of $\mathrm{GO}(\mathrm{a})$; of $\mathrm{CeO}_{2}$ with rGO-like organic residues (sample $\mathrm{rGO}(0)-\mathrm{CeO}_{2}$ ) (f); and of $\mathrm{rGO}-\mathrm{CeO}_{2}$ composites with different proportions of added $\mathrm{rGO}(\mathrm{b}-\mathrm{e})$ after solvothermal treatment in ethanol.

The D-band is related to a breathing mode of $\kappa$-point photons of $A_{1 g}$ symmetry, and the G-band can be attributed to the splitting of the $E_{2 g}$ stretching mode of graphite, which reflects the proportion of the $\mathrm{sp}^{2}$-hybridized carbon atoms [24]. The intensi- ty ratio $I(\mathrm{D}) / I(\mathrm{G})$ represents the degree of disorder in a graphite layer. The GO synthesized in this study showed the typical Dand G-band at $1351 \mathrm{~cm}^{-1}$ and $1590 \mathrm{~cm}^{-1}$, respectively, with an intensity ratio $I(\mathrm{D}) / I(\mathrm{G})$ of 0.97 . Generally, the G- and D-bands slightly shift to lower values when GO is reduced to graphene $[25,26]$.

No D- and G-band were observed in the Raman spectra (Supporting Information File 1, Figure S1) when (1) $\mathrm{H}_{2} \mathrm{O}$ was used instead of EtOH for solvothermal treatment or (2) cerium ammonium nitrate $\left(\mathrm{NH}_{4}\right)_{2}\left[\mathrm{Ce}\left(\mathrm{NO}_{3}\right)_{6}\right]$ was used as precursor instead of cerium tert-butoxide (identical preparation conditions in all cases). We did not check cerium alkoxides, $\mathrm{Ce}(\mathrm{OR})_{4}$, with other groups $\mathrm{R}$. This indicates that the appearance of residues with rGO-like structures is closely related to cerium tert-butoxide (or possibly $\mathrm{Ce}(\mathrm{OR})_{4}$ in general) as precursor and ethanol as the solvothermal solvent. The alcohol acts as a reductant for $\mathrm{GO}$.

In this study, varying proportions of pre-synthesized graphene oxide (GO) were introduced into the ceria gel to investigate its dispersion and its effect on structure and properties of the sol-gel ceria. Raman spectra showed that the D-bands of all $\mathrm{rGO}-\mathrm{CeO}_{2}$ composites were shifted to lower values (Figure 1), indicating that the GO had been reduced to graphene (rGO) during solvothermal processing in EtOH. The G-bands, however, were slightly shifted to higher values compared with that of GO. This can be attributed to the increased number of defects caused by stress from the oxygen states $[16,27,28]$ as indicated by the intensity ratio $I(\mathrm{D}) / I(\mathrm{G}) . I(\mathrm{D}) / I(\mathrm{G})$ values for all $\mathrm{rGO}-\mathrm{CeO}_{2}$ composites were larger than that of GO, indicating that the number of defects in the graphene layer increased during the reduction of $\mathrm{GO}[29,30]$. Anchoring of $\mathrm{CeO}_{2}$ on $\mathrm{rGO}$ also caused an intensity decrease and up-shifting of the G-band because of the electron transfer $[9,16]$.

The distribution of rGO was investigated by Raman mapping. Only the mappings for the samples with $0.2 \mathrm{~g}, 0.05 \mathrm{~g}$ and $0.02 \mathrm{~g}$ rGO are reproduced in Figure 2, because the Raman intensity for GO proportions of 0.1 and $0.05 \mathrm{~g}$ were almost the same. For a GO proportion of 0.05 and $0.02 \mathrm{~g}$, the Raman mapping showed no obvious phase separation, indicating that $\mathrm{rGO}$ and $\mathrm{CeO}_{2}$ were homogeneously dispersed. However, when the GO proportion was $0.2 \mathrm{~g}$, phase separation (agglomeration of $\mathrm{rGO}$ ) was observed by partial disappearance of the $\mathrm{CeO}_{2}$ signal and the enhancement of the rGO signal in the corresponding area. In this case, GO apparently cannot disperse well enough after solvothermal treatment.

The IR spectra of all $\mathrm{rGO}-\mathrm{CeO}_{2}$ composites (Figure 3) were almost the same, and only the peak intensities were somewhat 


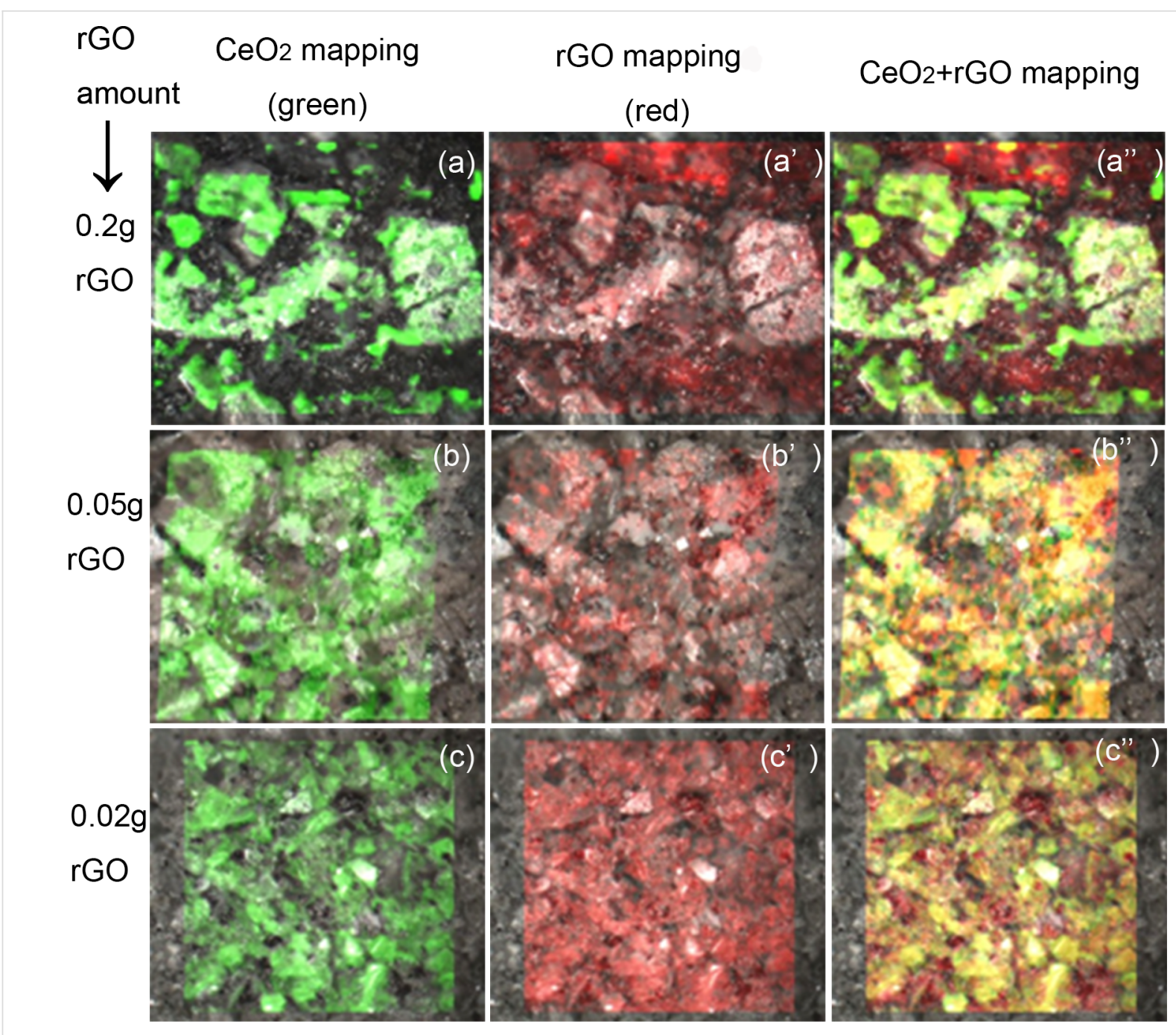

Figure 2: Raman mapping of $\mathrm{rGO}-\mathrm{CeO}_{2}$ composites with different proportions of $\mathrm{rGO}$ after solvothermal treatment in ethanol (mapping area: $500 \times 500 \mu \mathrm{m}^{2}$ ).

different. They also showed a clear transition from GO to rGO. GO has strong bands in the range of $3000-3500 \mathrm{~cm}^{-1}$ and $1000-1750 \mathrm{~cm}^{-1}$, which correspond to $\mathrm{OH}$ and $\mathrm{COO} / \mathrm{CO}$ groups, respectively. After the solvothermal treatment, the intensity of $\mathrm{OH}\left(3000-3500 \mathrm{~cm}^{-1}\right)$ and $\mathrm{C}-\mathrm{O}\left(1042 \mathrm{~cm}^{-1}\right)$ vibrations decreased while the intensity of COO $\left(1250-1700 \mathrm{~cm}^{-1}\right)$ increased, indicating that part of the defects were repaired and rGO was formed. Compared with the $\mathrm{COO}$ groups of GO (Figure $3 \mathrm{~b}$ ), the positions of $\mathrm{C}=\mathrm{O}$ bands shifted from $1719 \mathrm{~cm}^{-1}$ to $1492 \mathrm{~cm}^{-1}$. The shifts are most likely caused by coordination of graphene to $\mathrm{CeO}_{2}$ through the residual $\mathrm{COO}$ groups. The IR spectrum of the sample prepared without addition of $\mathrm{rGO}$ was similar to that of $0.02 \mathrm{~g}$ rGO. Part of the $\mathrm{COO}$ bands is most probably due to ceria-bound acetate groups, formed from ethanol either during the formation of $\mathrm{CeO}_{2}$ [18] or the reduction of GO. They cannot be distinguished spectroscopically from graphene-bound $\mathrm{COO}$ groups.
In the absence of externally added rGO, the TGA curve had only one shoulder at $150-250{ }^{\circ} \mathrm{C}$, corresponding to a weight loss of $12.3 \%$, as reported earlier [17]. The rGO-containing samples had an additional shoulder at $300-400{ }^{\circ} \mathrm{C}$, which is probably due to the formation of $\mathrm{rGO}$ (Supporting Information File 1, Figure S2). The weight loss generally increased with increasing rGO proportion $\left[12.4 \%\right.$ for $\mathrm{rGO}(0.02)-\mathrm{CeO}_{2}, 16.5 \%$ for $\mathrm{rGO}(0.05)-\mathrm{CeO}_{2}, 19.1 \%$ for $\mathrm{rGO}(0.1)-\mathrm{CeO}_{2}$, and $26.3 \%$ for $\mathrm{rGO}(0.2)-\mathrm{CeO}_{2}$ ]. All weight losses were larger than the amount of added GO due to the organic residues after solvothermal treatment (ca. 11\%). Thus, the formed rGO originates from both added $\mathrm{GO}$ and the organic residues.

Varying the proportion of GO (from 0 to $0.2 \mathrm{~g}$ ) did not influence the $\mathrm{CeO}_{2}$ crystallite size (1.9-2.6 nm, calculated from Scherrer's equation based on the strongest peak at $28.7^{\circ}$ ) to a large extent (Supporting Information File 1, Figure S3). The 


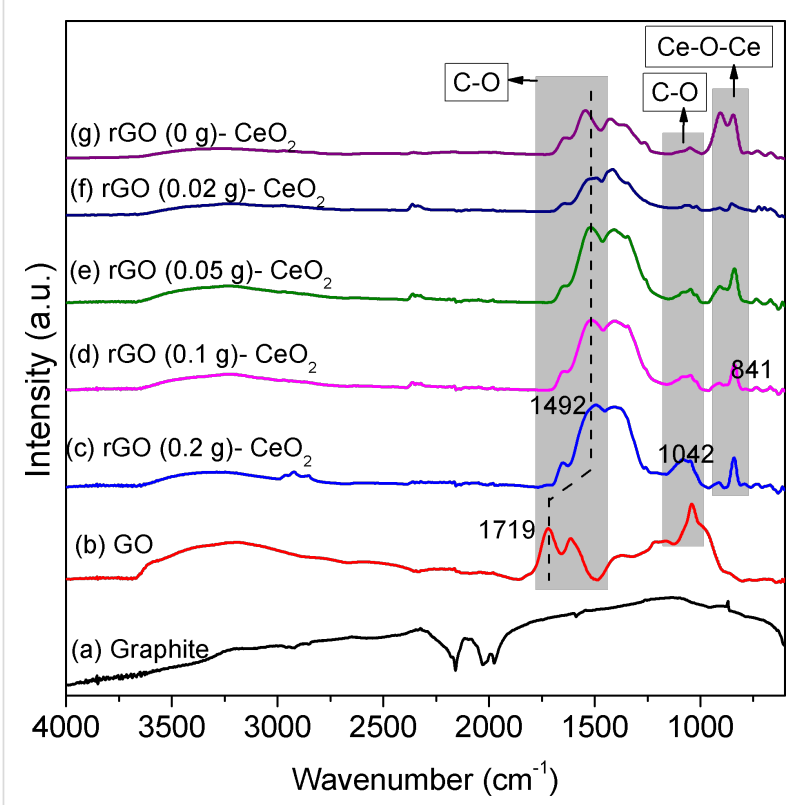

Figure 3: IR spectra of graphite (a); $\mathrm{GO}(\mathrm{b}) ; \mathrm{CeO}_{2}$ with rGO-like organic residues (sample $\left.\mathrm{rGO}(0)-\mathrm{CeO}_{2}\right)(\mathrm{g})$; $\mathrm{rGO}-\mathrm{CeO}_{2}$ composites with different proportions of added $\mathrm{rGO}(\mathrm{c}-\mathrm{f})$ after solvothermal treatment in ethanol.

particle size of the undoped sample was $1.9 \mathrm{~nm}$, and changed to $1.9-2.2 \mathrm{~nm}$ upon addition of $0.02-0.1 \mathrm{~g}$ GO. Only the sample $\mathrm{rGO}(0.2)-\mathrm{CeO}_{2}$ had a slightly larger $\mathrm{CeO}_{2}$ crystallite size $(2.6 \mathrm{~nm})$.

The TEM (Figure 4) were consistent with the XRD results and showed that $\mathrm{rGO}(0)-\mathrm{CeO}_{2}$ and $\mathrm{rGO}(0.05)-\mathrm{CeO}_{2}$ are formed by 2-4 nm ceria particles. The $\mathrm{rGO}$ sheets can be easily observed in $\mathrm{rGO}(0.05)-\mathrm{CeO}_{2}$, and $\mathrm{CeO}_{2}$ particles were attached to the rGO sheets.
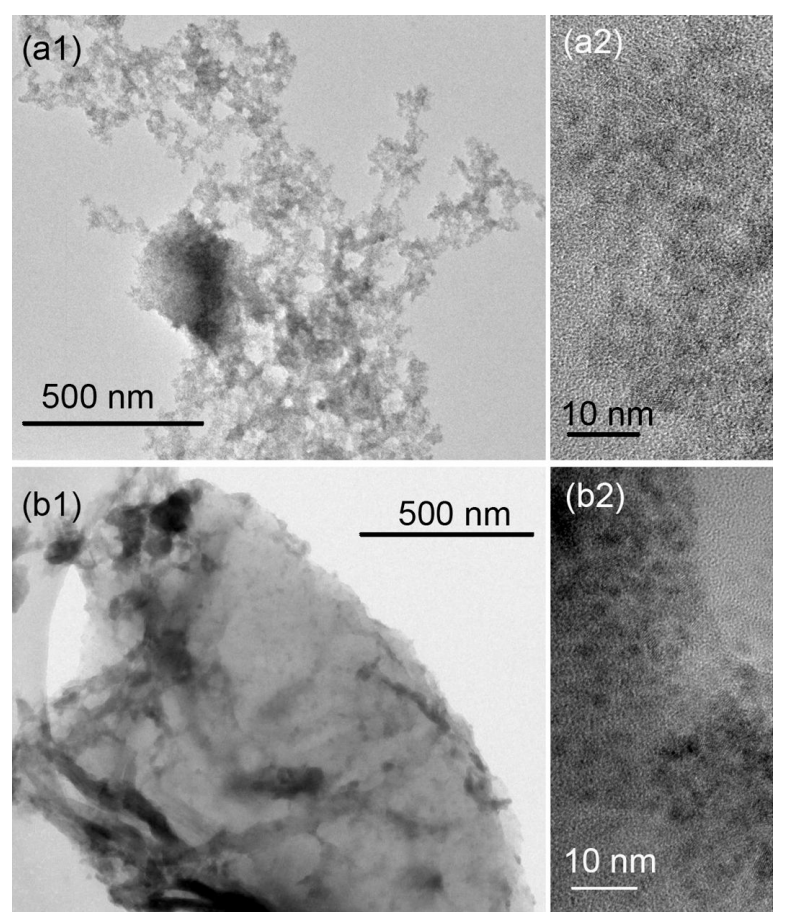

Figure 4: Morphologies of $\mathrm{rGO}(0)-\mathrm{CeO}_{2}(\mathrm{a} 1: \mathrm{TEM}, \mathrm{a} 2$ : HRTEM) and $\mathrm{rGO}(0.05)-\mathrm{CeO}_{2}$ (b1: TEM, b2: HRTEM).

$\mathrm{N}_{2}$ adsorption-desorption results for the $\mathrm{rGO}-\mathrm{CeO}_{2}$ composites with different proportions of $\mathrm{rGO}$ after solvothermal treatment are shown in Figure 5, left. Only $\mathrm{rGO}(0.2)-\mathrm{CeO}_{2}$ is mesoporous, according to the IUPAC classification, while the others contain mainly micropores and a small portion of mesopores. This can also be seen from the pore size distribution (Figure 5, right). $\mathrm{rGO}(0.2)-\mathrm{CeO}_{2}$ has an average pore size of $4.8 \mathrm{~nm}$, while the other samples have smaller pore size in the range of
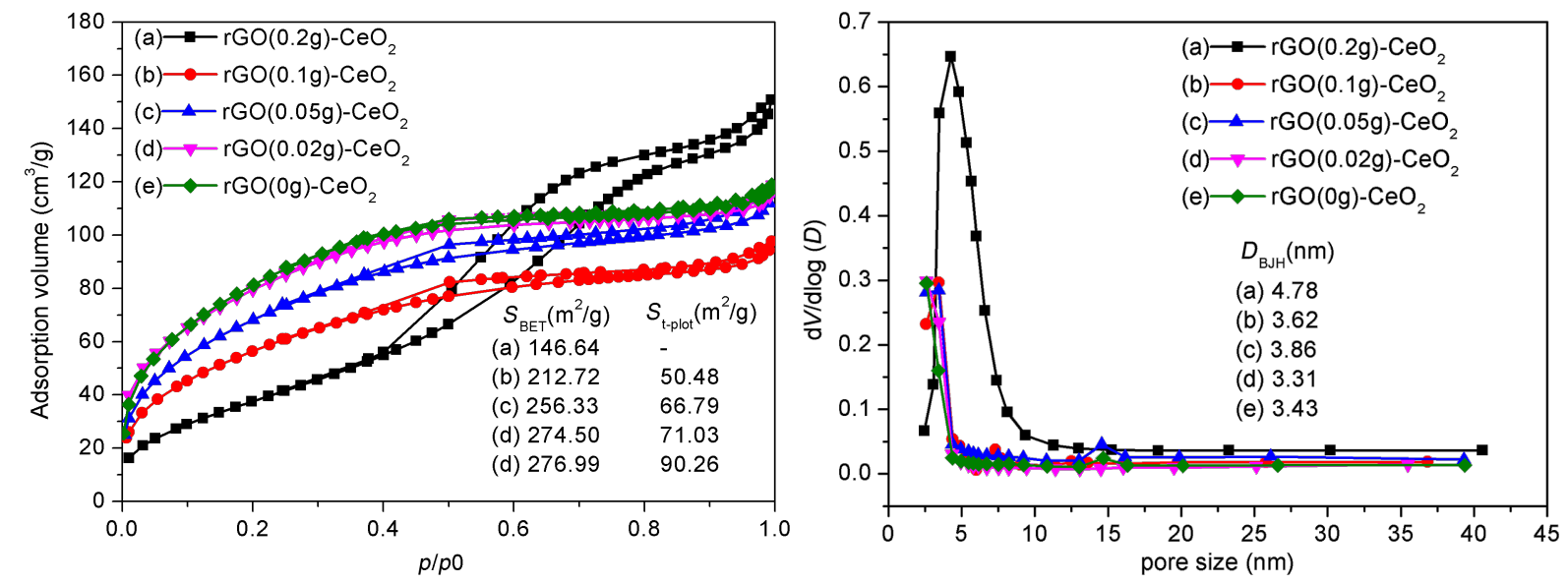

Figure 5: $\mathrm{N}_{2}$ adsorption-desorption isotherms (left) and pore size distributions (right) for $\mathrm{CeO}_{2}$ with $\mathrm{rGO}$-like organic residues ( $\left.\mathrm{rGO}(0)-\mathrm{CeO} 2\right)(\mathrm{e})$ and $\mathrm{rGO}-\mathrm{CeO}_{2}$ composites (a-d) with different proportions of $\mathrm{rGO}$ after solvothermal treatment with ethanol. 
$3.3-3.8 \mathrm{~nm}$. The surface area increased with decreasing rGO proportion, from $147 \mathrm{~m}^{2} / \mathrm{g}$ with $0.2 \mathrm{~g}$ rGO to $275 \mathrm{~m}^{2} / \mathrm{g}$ with $0.02 \mathrm{~g} \mathrm{rGO}$. $\mathrm{GGO}(0)-\mathrm{CeO}_{2}$ and $\mathrm{rGO}(0.02)-\mathrm{CeO}_{2}$ processed almost the same surface area.

The influence of the rGO proportion on the catalytic activity for $\mathrm{CO}$ oxidation was tested for $\mathrm{rGO}(0.05)-\mathrm{CeO}_{2}$ compared to $\mathrm{rGO}(0)-\mathrm{CeO}_{2}$ under the same conditions (Figure 6). The catalytic activity of $\mathrm{rGO}(0.05)-\mathrm{CeO}_{2}$ was higher than that of $\mathrm{rGO}(0)-\mathrm{CeO}_{2}$. Both samples were also calcined at $500{ }^{\circ} \mathrm{C}$ for $2 \mathrm{~h}$ to remove $\mathrm{rGO}$ and the organic residues (samples marked with AC). After calcination, the surface area of $\mathrm{rGO}(0.05)-\mathrm{CeO}_{2}$ was reduced from 256.3 to $55.5 \mathrm{~m}^{2} / \mathrm{g}$ and that of $\mathrm{rGO}(0)-\mathrm{CeO}_{2}$ from 276.9 to $88.9 \mathrm{~m}^{2} / \mathrm{g}$. The activity of $\mathrm{rGO}(0.05)-\mathrm{CeO}_{2}-\mathrm{AC}$ is somewhat lower than that of $\mathrm{rGO}(0.05)-\mathrm{CeO}_{2}$ at the same temperature, but still higher than that of $\mathrm{rGO}(0)-\mathrm{CeO}_{2}-\mathrm{AC}$. For example, $r_{250}{ }^{\circ} \mathrm{C}$ (the reaction rate at $250{ }^{\circ} \mathrm{C}$ per gram catalyst) for $\mathrm{rGO}(0.05)-\mathrm{CeO}_{2}$ during first heating is $1.19 \cdot 10^{-5}$ changed to $8.77 \cdot 10^{-6} \mathrm{~mol} / \mathrm{s} \cdot \mathrm{g}$ for $\mathrm{rGO}(0.05)-\mathrm{CeO}_{2}-\mathrm{AC}$. This decrease is possibly caused by the removal of graphene and reduction of the surface area.

The advantage of the $\mathrm{rGO}(0.05)-\mathrm{CeO}_{2}$ composite can also be seen from the $\mathrm{CO}$ temperature-programmed reduction (COTPR) (Figure 7). Both $\mathrm{CO}_{2}$ and $\mathrm{H}_{2}$ evolution showed signals at lower temperatures (ca. $100{ }^{\circ} \mathrm{C}$ ) for $\mathrm{rGO}(0.05)-\mathrm{CeO}_{2}$ than for $\mathrm{rGO}(0)-\mathrm{CeO}_{2}$. Similar to $\mathrm{rGO}(0)-\mathrm{CeO}_{2}, \mathrm{rGO}(0.05)-\mathrm{CeO}_{2}$ also showed three features: removal of surface lattice oxygen (below $300{ }^{\circ} \mathrm{C}$ ), water-gas shift between $\mathrm{CO}$ and surface $\mathrm{OH}$ groups $\left(300-500{ }^{\circ} \mathrm{C}\right.$ ), and extraction of bulk oxygen (above $500{ }^{\circ} \mathrm{C}$ ), respectively, as discussed previously [17].

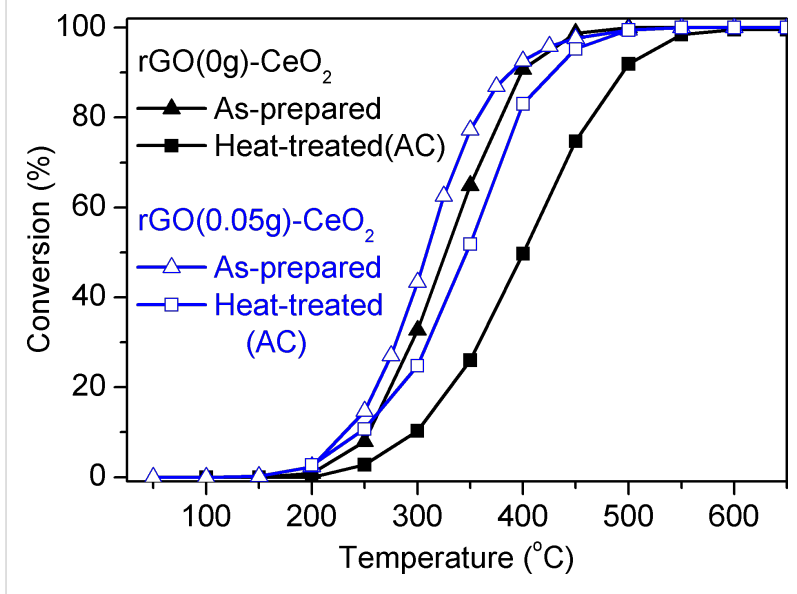

Figure 6: $\mathrm{CO}$ oxidation at different temperatures for $\mathrm{CeO}_{2}$ with rGOlike organic residues $\left(\mathrm{rGO}(0)-\mathrm{CeO}_{2}\right)$ and the $\mathrm{rGO}(0.05)-\mathrm{CeO}_{2} \mathrm{com}$ posite.

\section{Conclusion}

We have shown in this article that the organic residues generated upon solvothermal treatment of ceria gels, obtained by sol-gel processing of cerium tert-butoxide, in ethanol as solvent [17] contain reduced graphene oxide (rGO)-like structures. The appearance of rGO-like structures can be associated with cerium tert-butoxide (or possibly cerium alkoxides in general) as precursor and ethanol as solvothermal solvent, and may also explain the higher catalytic activity (compared with, for example hydrothermally treated samples). This was also confirmed by introduction of "external" graphene oxide during sol-gel processing, by which the rGO structures and the catalytic activity were enhanced. The previously observed higher catalytic CO
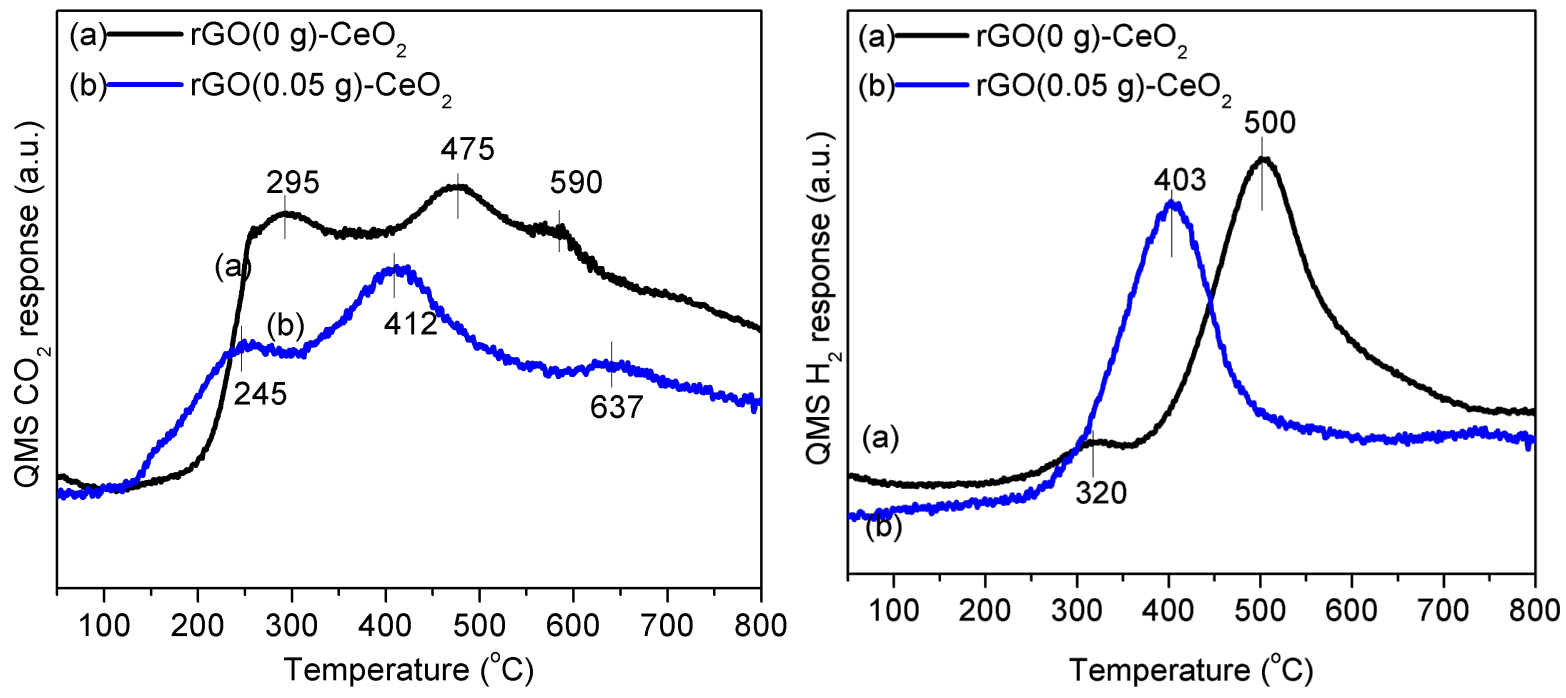

Figure 7: $\mathrm{CO}_{2}$ (left) and $\mathrm{H}_{2}$ (right) evolution during $\mathrm{CO}-\mathrm{TPR}$ over $\mathrm{rGO}(0)-\mathrm{CeO}_{2}$ and $\mathrm{rGO}(0.05)-\mathrm{CeO}_{2}$. 
oxidation activity of ceria samples solvothermally treated in ethanol can therefore be traced back to the presence of rGO structures [17].

\section{Supporting Information}

\section{Supporting Information File 1}

Additional experimental data.

[http://www.beilstein-journals.org/bjnano/content/

supplementary/2190-4286-7-174-S1.pdf]

\section{Acknowledgements}

This project was supported by the Austrian Science Funds (FWF) in the framework of the Doctoral School Building Solids for Function (Project W1243). The authors thank Christine Artner for the XRD measurements, and Liliana Lukashuk and Karin Föttinger for the access to and help for catalytic measurements.

\section{References}

1. Yan, T.; Li, R.; Zhu, H.; Li, Z. Mater. Res. Bull. 2016, 78, 163-171. doi:10.1016/j.materresbull.2016.02.024

2. Vanitha, M.; Keerthi; Cao, P.; Balasubramanian, N. J. Alloys Compd. 2015, 644, 534-544. doi:10.1016/j.jallcom.2015.03.221

3. Dezfuli, A. S.; Ganjali, M. R.; Norouzi, P.; Faridbod, F. J. Mater. Chem. B 2015, 3, 2362-2370. doi:10.1039/C4TB01847H

4. Su, Q.; Chang, L.; Zhang, J.; Du, G.; Xu, B. J. Phys. Chem. C 2013, 117, 4292-4298. doi:10.1021/jp312169j

5. Wang, G.; Bai, J.-T.; Wang, Y.-H.; Ren, Z.-Y.; Bai, J.-B. Scr. Mater. 2011, 65, 339-342.

6. Yu, X.; Kuai, L.; Geng, B. Nanoscale 2012, 4, 5738-5743. doi:10.1039/c2nr31765f

7. Kuila, T.; Mishra, A. K.; Khanra, P.; Kim, N. H.; Lee, J. H. Nanoscale 2013, 5, 52-71. doi:10.1039/C2NR32703A

8. Xiao, X.; Sheng, Z.; Yang, L.; Dong, F. Catal. Sci. Technol. 2016, 6, 1507-1514. doi:10.1039/C5CY01228G

9. Yang, Y.; Tian, C.; Sun, L.; Lü, R.; Zhou, W.; Shi, K.; Kan, K.; Wang, J.; Fu, H. J. Mater. Chem. A 2013, 1, 12742-12749. doi:10.1039/c3ta12399e

10. Kakaei, K.; Rahimi, A.; Husseindoost, S.; Hamidi, M.; Javan, H.; Balavandi, A. Int. J. Hydrogen Energy 2016, 41, 3861-3869. doi:10.1016/j.ijhydene.2016.01.013

11. Jiang, L.; Yao, M.; Liu, B.; Li, Q.; Liu, R.; Lv, H.; Lu, S.; Gong, C.; Zou, B.; Cui, T.; Liu, B.; Hu, G.; Wågberg, T. J. Phys. Chem. C 2012, 116, 11741-11745. doi:10.1021/jp3015113

12. Srivastava, M.; Das, A. K.; Khanra, P.; Uddin, M. E.; Kim, N. H.; Lee, J. H. J. Mater. Chem. A 2013, 1, 9792-9801. doi:10.1039/c3ta11311f

13. Ji, Z.; Shen, X.; Xu, Y.; Zhu, G.; Chen, K. J. Colloid Interface Sci. 2014, 432, 57-64. doi:10.1016/j.jcis.2014.06.045

14. Kumar, S.; Ojha, A. K.; Patrice, D.; Yadav, B. S.; Materny, A. Phys. Chem. Chem. Phys. 2016, 18, 11157-11167. doi:10.1039/C5CP04457J

15. Ji, Z.; Shen, X.; Li, M.; Zhou, H.; Zhu, G.; Chen, K. Nanotechnology 2013, 24, 115603. doi:10.1088/0957-4484/24/11/115603
16. Ling, Q.; Yang, M.; Rao, R.; Yang, H.; Zhang, Q.; Liu, H.; Zhang, A. Appl. Surf. Sci. 2013, 274, 131-137. doi:10.1016/j.apsusc.2013.02.129

17. Yang, J.; Lukashuk, L.; Li, H.; Föttinger, K.; Rupprechter, G.; Schubert, U. Catal. Lett. 2014, 144, 403-412. doi:10.1007/s10562-013-1162-8

18. Slostowski, C.; Marre, S.; Babot, O.; Toupance, T.; Aymonier, C. Langmuir 2012, 28, 16656-16663. doi:10.1021/la303265t

19. Yang, J.; Lukashuk, L.; Akbarzadeh, J.; Stöger-Pollach, M.; Peterlik, H.; Föttinger, K.; Rupprechter, G.; Schubert, U. Chem. - Eur. J. 2015, 21, 885-892. doi:10.1002/chem.201403636

20. Hummers, W. S., Jr.; Offeman, R. E. J. Am. Chem. Soc. 1958, 80, 1339. doi:10.1021/ja01539a017

21. Kovtyukhova, N. I.; Ollivier, P. J.; Martin, B. R.; Mallouk, T. E.; Chizhik, S. A.; Buzaneva, E. V.; Gorchinskiy, A. D. Chem. Mater. 1999, 11, 771-778. doi:10.1021/cm981085u

22. Ferrari, A. C.; Robertson, J. Philos. Trans. R. Soc. London, Ser. A 2004, 362, 2477-2512. doi:10.1098/rsta.2004.1452

23. Schwan, J.; Ulrich, S.; Batori, V.; Ehrhardt, H.; Silva, S. R. P. J. Appl. Phys. 1996, 80, 440-447. doi:10.1063/1.362745

24. Ferrari, A. C.; Basko, D. M. Nat. Nanotechnol. 2013, 8, 235-246. doi:10.1038/nnano.2013.46

25. Stankovich, S.; Dikin, D. A.; Piner, R. D.; Kohlhaas, K. A.; Kleinhammes, A.; Jia, Y.; Wu, Y.; Nguyen, S. T.; Ruoff, R. S. Carbon 2007, 45, 1558-1565. doi:10.1016/j.carbon.2007.02.034

26. Lambert, T. N.; Chavez, C. A.; Hernandez-Sanchez, B.; Lu, P.; Bell, N. S.; Ambrosini, A.; Friedman, T.; Boyle, T. J.; Wheeler, D. R.; Huber, D. L. J. Phys. Chem. C 2009, 113, 19812-19823. doi:10.1021/jp905456f

27. Joung, D.; Singh, V.; Park, S.; Schulte, A.; Seal, S.; Khondaker, S. I. J. Phys. Chem. C 2011, 115, 24494-24500. doi:10.1021/jp206485v

28. Lee, J.; Novoselov, K. S.; Shin, H. S. ACS Nano 2011, 5, 608-612. doi:10.1021/nn103004c

29. Fu, Y.; Wang, X. Ind. Eng. Chem. Res. 2011, 50, 7210-7218. doi:10.1021/ie200162a

30. Fan, Z.-J.; Kai, W.; Yan, J.; Wei, T.; Zhi, L.-J.; Feng, J.; Ren, Y.-m.; Song, L.-P.; Wei, F. ACS Nano 2011, 5, 191-198. doi:10.1021/nn102339t

\section{License and Terms}

This is an Open Access article under the terms of the Creative Commons Attribution License (http://creativecommons.org/licenses/by/4.0), which permits unrestricted use, distribution, and reproduction in any medium, provided the original work is properly cited.

The license is subject to the Beilstein Journal of Nanotechnology terms and conditions: (http://www.beilstein-journals.org/bjnano)

The definitive version of this article is the electronic one which can be found at: doi:10.3762/bjnano.7.174 